\title{
The Impact of Dairy Effluent on Germination Parameters of Seeds of Mung bean (Vigna radiata) and Mustard (Brassica nigra)
}

\author{
Jyoti Kapil* and Neetika Mathur
}

Dept. of Biotechnology, Kanoria P.G MahilaMahavidyalaya, Jaipur, Rajasthan (302 004), India

\section{Corresponding Author}

Jyoti Kapil

e-mail: jyotikapil31@gmail.com
Article History

Article ID: IJEP0386

Received in $19^{\text {th }}$ September, 2020

Received in revised form $10^{\text {th }}$ October, 2020

Accepted in final form $19^{\text {th }}$ October, 2020

\begin{abstract}
The advancement of a country depends upon its industrialization. Of all industrial sectors, the food processing units have highest consumption of water and are biggest producers of effluent per unit of production.The concentration and composition of the effluent depends upon operating methods andthe size and design of the processing plant.The dairy industry generates on an average 6-10 litres of waste water per litre of the milk processed. It has relatively high organic matter, suspended solids, trace organic nutrients which are essential for growth of crop plant. Thus, the utilization of the dairy effluent for irrigation can be an eco friendly approach for its disposal. The present study was carried out to study the influence of dairy effluent on seed germination, seedling growth and biomass production in mung bean (Vigna radiata) and mustard (Brassica nigra). The seeds of both the plant species were grown in petriplates and pots irrigated with various concentrations of dairy effluent $(20,40,60,80$ and $100 \%)$. The dairy effluent concentration of $20 \%$ was more favorable for total growth parameters viz., the germination percentage, the shoot length, dry weight and wet weight both in mustard and mung bean. Among different concentrations, $100 \%$ concentration of effluent caused inhibitory effect. Thus, it is recommended that only after suitable dilution, the dairy effluent can be effectively used for irrigation.
\end{abstract}

Keywords: Dairy effluent, mung bean, mustard, germination, seedling growth

\section{Introduction}

The advancement of a country depends upon its industrialization. But water pollution caused by industries is a serious concern throughout the world (Braio and Taveres, 2007; Mustafa et al., 2010). Of all industrial sectors, the food processing units have highest consumptions of water and are biggest producers of effluent per unit of production (Ramjeawon, 2000; Prabhakar et al., 2006; Tikariha and Sahu, 2014). Safe disposal of industrial effluent has become an ecological challenge. Continuous disposal of waste water into the water bodies has deteriorated surface water quality because of the mixing of various chemical pollutants of the effluent with water (WHO, 2003; Al-Dulaimi et al., 2014; Khaleel et al., 2012). The physicochemical techniques used for removing pollutants from the environment are inefficient, costly, of limited applicability, and sometimes producing large amounts of toxic waste which is difficult to dispose off or form hazardous by-product. The lack of efficient effluent treatment facilities and proper system of waste water disposal has increased pollution of water bodies day by day and adversely effected soil, water, flora and fauna due to presence of toxic and persistent chemicals.

The industrial effluent has been used for agricultural irrigation in developing as well as developed countries. The soil has a great capacity for receiving and decomposing various types of wastes and pollutants and thus it act as an excellent purifying media. The land disposal of agricultural, dairy, municipal and industrial waste is widely practiced as a major and economic source of nutrients and organic matter for growing cereal in arid and semi-arid regions of the country, where shortage of water becomes limiting factor (Gaikar et al., 2010). Further, the industrial effluent is rich in plant nutrients and can be effectively utilized as liquid bio-fertilizer for the soil restoration and sustainable land production.The usage of the treated effluent for recreational activities is due to the demand of the water worldwide. Thus, Finding suitable eco-friendly techniques for the potential utilization of these released effluents as a source of nutrients become essential (Parmar et al., 2017). The effluents generated from food processing industries like fruits and vegetable processing, meat and poultry processing, dairy industries etc are rich in nutrients like carbohydrates, minerals and nitrogenous compounds which when supplied in optimal concentrations enhance the plant growth (Kumar, 2011; Kumar et al., 2013).

In India, dairy industry is one of the most important agrobased industries and is important commodity entering trades. The dairy operations involve processing of raw milk into pasteurised and sour milk, hard, soft and cottage cheese, 
cream and butter products, ice cream, yoghurt, milk powders, condensed milk and various types of dessertsfor the consumer. Enormous amount of water is used in various stages of dairy operations, such as, milk processing, cleaning, packaging and cleaning of the milk tankers and resulting in generation of significant quantities of waste water which is known as dairy effluent (Belyea et al., 1990; Manu et al., 2012). The quantity of dairy effluent released by a milk processing plant depends upon the size of the plant, generally expressed in terms of the maximum weight of milk handled in a single day, and the processes involved.The dairy industry generates on an average 6-10 litres of waste water per litre of the milk processed. It has relatively high organic matter, suspended solids, trace organics nutrients, inorganic nutrients which are essential for growth of crop plant (FAO, 1992; Kharbanda and Prasana, 2016; Verma and Singh, 2017).

The present investigation was carried out to study the effective and suitable concentrations of dairy effluent in promoting germination, wet weight and dry weight of mung bean (Vigna radiata) and mustard (Brassica nigra). The study also aimed at physicochemical characterization of effluent from Jaipur dairy.

\section{Materials and Methods}

\subsection{Experimental procedure}

The study was conducted in biotechnology laboratory at the Kanoria P. G. Mahila Mahavidyalaya, Jaipur to study the effect of dairy effluent on the germination of seeds of mung bean (Vigna radiata) and mustard (Brassica nigra) in November 2019. Maximum temperature during the study period varied between $18^{\circ} \mathrm{C}-32^{\circ} \mathrm{C}$.

\subsection{Sample area and sample collection}

The effluent samples were collected from Jaipur Dairy from a discharge point in a clean plastic container which was rinsed with $\mathrm{HNO}_{3}$ and distilled water. The sample container transferred to biotechnology laboratory and stored at $4^{\circ} \mathrm{C}$ until used for further analysis.

\subsection{Physicochemical characterization of dairy effluent}

Effluent samples were analyzed for physico-chemical parameters such as $\mathrm{pH}$, temperature, salinity, nitrate, BOD and COD by standard protocols given in American Public Health Association (APHA) (1998). Color, temperature and $\mathrm{pH}$ of the effluent were recorded at the sampling point. All other parameters were analyzed within $24 \mathrm{hrs}$.

\subsection{Seed germination experiment}

Effluent samples were analyzed for physico-chemical parameters such as $\mathrm{pH}$, temperature, salinity, nitrate, BOD and COD by standard protocols given in American Public Health Association (APHA) (1998). Color, temperature and $\mathrm{pH}$ of the effluent were recorded at the sampling point. All other parameters were analyzed within $24 \mathrm{hrs}$.

\subsection{Seed germination experiment}

The healthy seeds of Mung bean and Mustard were selected and surface sterilized with $0.1 \%$ mercuric chloride $\left(\mathrm{HgCl}_{2}\right)$ and washed with distilled water. Twenty seeds were placed equispacially in sterilized petriplates which were lined with filter paper soaked with different concentrations of effluent (20\%, 40\%, 60\%, 80\% and $100 \%$ ) and tap water as control. These petriplates were irrigated with different concentration of effluent uniformly. Number of seeds germinated was counted on $7^{\text {th }}$ day and total growth parameters viz., the germination percentage, the shoot length, dry weight and wet weight were calculated. The shoot length was measured at the area of contact between the stem and root; mean shoot length was expressed in centimetres using a measuring tape $(\mathrm{cm})$. The wet weight of seedlings was taken and then they were dried overnight in oven and again weighed for estimation of the dry weight. Data were taken from three replicates of seedlings.

\subsection{Statistical analysis}

The values of different parameters are presented as mean of replications. The treatments were designed in completely randomized block design with three replications. The statistical analysis was done by using online software OPSTAT.

\section{Results and Discussion}

\subsection{Physicochemical characterization of dairy effluent}

From the data presented in Table 1, it is clear that dairy effluent was white in colour. The $\mathrm{pH}$ and temperature of the effluent was recorded as 6.8 and $26^{\circ} \mathrm{C}$, respectively. These results were similar to the findings by Dhanam (2009) for dairy industrial effluents. Dairy waste streams have higher annual temperature $\left(17-25^{\circ} \mathrm{C}\right)$ than that of municipal waste water $\left(10-20^{\circ} \mathrm{C}\right)$, thus, a faster biological degradation occurs in dairy waste water as compared to sewage treatment plants (Ahmad

Table 1: Physicochemical characterization of dairy effluent

\begin{tabular}{|c|c|c|c|c|}
\hline $\begin{array}{l}\text { Sl. } \\
\text { No. }\end{array}$ & Parameters & Units & Values & $\begin{array}{c}\text { Permissible limits } \\
\text { (APHA) }\end{array}$ \\
\hline 1. & Colour & - & White & - \\
\hline 2. & $\mathrm{pH}$ & - & 6.8 & $6.5-8.5$ \\
\hline 3. & $\begin{array}{l}\text { Tempera- } \\
\text { ture }\end{array}$ & ${ }^{\circ} \mathrm{C}$ & 26 & $\begin{array}{l}\text { shall not exceed } 5^{\circ} \mathrm{C} \\
\text { above the receiving } \\
\text { water temperature }\end{array}$ \\
\hline 4. & Alkalinity & $\mathrm{mg} \mathrm{l}^{-1}$ & 1.93 & - \\
\hline 5. & Chlorides & $\mathrm{mg} \mathrm{l}^{-1}$ & 260 & 600 \\
\hline 6. & Nitrate & $\mathrm{mg} \mathrm{l}^{-1}$ & 22 & 10 \\
\hline 7. & BOD & $\mathrm{mg} \mathrm{l}^{-1}$ & 310 & 30 \\
\hline 8. & COD & $\mathrm{mg} \mathrm{l}^{-1}$ & 680 & 250 \\
\hline
\end{tabular}

et al., 2019). The values of alkalinity, chlorides, nitrate, BOD and COD of the effluent were $1.93 \mathrm{mg} \mathrm{l}^{-1}, 260 \mathrm{mg} \mathrm{l}^{-1}, 22 \mathrm{mg} \mathrm{l}^{-1}$, $310 \mathrm{mg} \mathrm{l}^{-1}, 680 \mathrm{mg} \mathrm{l}^{-1}$, respectively.

\subsection{Seed germination experiment}

Among various concentrations ranging from $20 \%$ to $100 \%$, the dairy effluent samples showed favourable effects on seed germination and other growth parameters of both mung bean 
and mustard. The results presented in Table 2 revealed that among various effluent concentrations, maximum percent germination of seeds of Mung bean (97\%) in petriplates was observed with $20 \%$ effluent concentration which is statistically at par with that of control (tap water), $60 \%$ and $80 \%$ effluent concentration. The minimum germination ( $80 \%$ ) of mung bean

Table 2: Effect of different concentrations of dairy effluent on percentage germination of Mung bean seeds

\begin{tabular}{lcc}
\hline $\begin{array}{l}\text { Concentration of } \\
\text { effluent (\%) }\end{array}$ & $\begin{array}{c}\text { Germination (\%) } \\
\text { in petriplates }\end{array}$ & $\begin{array}{c}\text { Germination (\%) } \\
\text { in pots }\end{array}$ \\
\hline 20 & $97^{\mathrm{a}}$ & $84^{\mathrm{a}}$ \\
& $(9.89)^{*}$ & $(66.70)^{* *}$ \\
40 & $85^{\mathrm{b}}$ & $52^{\mathrm{b}}$ \\
& $(8.77)$ & $(46.32)$ \\
60 & $95^{\mathrm{a}}$ & $60 \mathrm{~b}$ \\
80 & $(9.79)$ & $(51.00)$ \\
& $95^{\mathrm{a}}$ & $83^{\mathrm{a}}$ \\
100 & $(9.79)$ & $(65.64)$ \\
& $80^{\mathrm{c}}$ & $25^{\mathrm{c}}$ \\
Control & $(9.00)$ & $(29.82)$ \\
& $100^{\mathrm{a}}$ & $85^{\mathrm{a}}$ \\
CD $(p=0.05)$ & $(9.89)$ & $(67.31)$ \\
SEm \pm & 0.262 & 6.227 \\
\hline
\end{tabular}

*Figures in parentheses are square root transformed values;

**Figures in parentheses are angular transformed values

seeds was at $100 \%$ effluent concentration. Similar results were obtained in pots, the seeds of mung bean showed maximum percentage germination at $20 \%$ effluent concentration (84\%) which was statistically at par with that of control and $80 \%$ effluent concentration. Lower concentration of dairy effluent showed promoting effect on seed germination, seedling growth, dry matter production (Dhanam, 2009). The minimum percentage germination (25\%) was observed at $100 \%$ effluent concentration. Results of present investigation are supported by the previous work on black gram and green gram irrigated by dairy effluent (Prasannakumar et al., 1997). The promotion of seedling growth by lower concentration of effluent might be due to the presence of plant nutrient in the effluent.

In case of mustard seeds grown in petriplates, the highest percentage germination (100\%) was recorded at $20 \%$ effluent concentration which was statistically at par with that of control (95\%). In pots, the maximum mustard seed germination (52\%) was recorded at control which was at par with seed germination at 20\% (48\%) and 60\% (45\%) effluent concentration (Table 3).

The dairy effluent at low concentration had greatly supported the growth of both mung bean and mustard seedlings. From Table 4, it could be inferred that there is statistically significant differences in seedling growth $(\mathrm{cm})$, wet weight and dry matter production $(\mathrm{g})$ depending on the concentration of

Table 3: Effect of different concentrations of dairy effluent on the percentage germination of Mustard seeds

\begin{tabular}{lcc}
\hline $\begin{array}{l}\text { Concentration of } \\
\text { effluent (\%) }\end{array}$ & $\begin{array}{c}\text { Petriplate } \\
\text { Germination (\%) }\end{array}$ & $\begin{array}{c}\text { Pot } \\
\text { Germination (\%) }\end{array}$ \\
\hline 20 & $100^{\mathrm{a}^{*}}$ & $48^{\mathrm{ab} * *}$ \\
& $(10.05)$ & $(40.18)$ \\
40 & $72 \mathrm{c}$ & $30^{\mathrm{b}}$ \\
& $(8.517)$ & $(33.02)$ \\
60 & $80^{\mathrm{b}}$ & $45^{\mathrm{a}}$ \\
& $(8.97)$ & $(42.01)$ \\
80 & $90^{\mathrm{ab}}$ & $48^{\mathrm{a}}$ \\
& $(9.56)$ & $(44.02)$ \\
100 & $80^{\mathrm{b}}$ & $32^{\mathrm{b}}$ \\
& $(8.99)$ & $(34.16)$ \\
Control & $95^{\mathrm{a}}$ & $52^{\mathrm{a}}$ \\
& $(9.79)$ & $(45.94)$ \\
CD $(p=0.05)$ & 0.699 & 7.808 \\
SEm & 0.224 & 2.506 \\
\hline
\end{tabular}

*Figures in parentheses are square root transformed values;

**Figures in parentheses are angular transformed values

effluent used. In case of mung bean, seedling in petriplates, the maximum shoot length $(5 \mathrm{~cm}$ ) was recorded in the $20 \%$ concentration which was statistically at par with that of control. This is followed by growth of seedling at $80 \%(2.26$ $\mathrm{cm}), 60 \%(2.20 \mathrm{~cm})$ and $40 \%(1.95 \mathrm{~cm})$ and $100 \%$ effluent $(1.78 \mathrm{~cm})$.

The magnitude of reduction in seed germination and seedling growth was higher at $100 \%$ concentration which may be probably due to higher osmotic pressure. Nagda et al. (2006) also reported that osmotic pressure of the effluent at higher concentration of total salt makes imbibition more difficult and retards germination. Suppression of seedling growth by effluent concentrations above $20 \%$ observed in the present study is in reference with the earlier studies of Singh et al. (2002) in Triticum aestivum, Gaikar et al. (2010) in Soyabeans, Lakshmi and Sundaramoorthy (2000) in Ragi and Koushik et al. (2005) in wheat.

In Petri plates, maximum dry weight $(0.52 \mathrm{~g})$ and wet weight $(2.12 \mathrm{~g})$ of mung bean seedlings was recorded at 20 and $60 \%$ effluent concentration, respectively (Table 4). However, in pot experiment, the seedlings showed maximum dry weight $(0.41 \mathrm{~g})$ and wet weight (1.98) at $20 \%$ effluent concentration (Table 5).

However, the seedlings of mung bean when grown in pots showed maximum shoot growth $(10.14 \mathrm{~cm})$ with $40 \%$ effluent concentration and it was at par with the $20 \%$ effluent $(9.26$ $\mathrm{cm})$. Further, the increase in effluent concentration from $60-$ 


\begin{tabular}{lccc}
\hline $\begin{array}{l}\text { Table 4: Effect of dairy effluents on growth parameters of } \\
\text { mung bean in petriplates }\end{array}$ \\
$\begin{array}{l}\text { Concentration of } \\
\text { effluent (\%) }\end{array}$ & $\begin{array}{c}\text { Shoot length } \\
(\mathrm{cm})\end{array}$ & $\begin{array}{c}\text { Dry } \\
\text { weight }(\mathrm{g})\end{array}$ & $\begin{array}{c}\text { Wet weight } \\
(\mathrm{g})\end{array}$ \\
\hline 20 & $5^{\mathrm{a}}$ & $0.52^{\mathrm{a}}$ & $1.49 \mathrm{c}$ \\
& $(5.00)^{*}$ & $(0.52)^{*}$ & $(1.49)^{*}$ \\
40 & $1.95^{\mathrm{b}}$ & $0.40^{\mathrm{b}}$ & $1.12^{\mathrm{d}}$ \\
& $(2.13)$ & $(0.40)$ & $(1.13)$ \\
60 & $2.2 \mathrm{~b}$ & $0.43^{\mathrm{b}}$ & $2.12^{\mathrm{a}}$ \\
& $(2.47)$ & $(0.43)$ & $(2.13)$ \\
80 & $2.26^{\mathrm{b}}$ & $0.41^{\mathrm{b}}$ & $1.98^{\mathrm{a}}$ \\
& $(2.27)$ & $(0.41)$ & $(2.00)$ \\
100 & $1.78^{\mathrm{b}}$ & $0.18^{\mathrm{c}}$ & $1.76^{\mathrm{b}}$ \\
& $(1.80)$ & $(0.19)$ & $(1.76)$ \\
Control & 4.43 & 0.38 & 1.41 \\
& $(4.67)^{\mathrm{a}}$ & $(0.39)^{\mathrm{b}}$ & $(1.40)^{\mathrm{c}}$ \\
CD $(p=0.05)$ & 0.983 & 0.071 & 0.192 \\
SEm \pm & 0.316 & 0.023 & 0.062 \\
\hline
\end{tabular}

*Figures in parentheses are square root transformed values

Table 5: Effect of dairy effluents on growth parameters of Mung bean in pots

\begin{tabular}{lccc}
\hline $\begin{array}{l}\text { Concentration of } \\
\text { effluent }(\%)\end{array}$ & $\begin{array}{c}\text { Shoot length } \\
(\mathrm{cm})\end{array}$ & $\begin{array}{c}\text { Dry } \\
\text { weight }(\mathrm{g})\end{array}$ & $\begin{array}{c}\text { Wet weight } \\
(\mathrm{g})\end{array}$ \\
\hline 20 & $9.26^{\mathrm{a}}$ & $0.41^{\mathrm{a}}$ & $1.98^{\mathrm{a}}$ \\
& $(9.267)^{*}$ & $(0.41)^{*}$ & $(1.98)$ \\
40 & $10.14^{\mathrm{a}}$ & $0.21^{\mathrm{c}}$ & $0.95^{\mathrm{c}}$ \\
& $(10.83)$ & $(0.21)$ & $(0.95)$ \\
60 & $8.3^{\mathrm{b}}$ & $0.23^{\mathrm{c}}$ & $1.12^{\mathrm{bc}}$ \\
& $(8.33)$ & $(0.23)$ & $(1.12)$ \\
80 & $6.5^{\mathrm{c}}$ & $0.33^{\mathrm{b}}$ & $1.44^{\mathrm{b}}$ \\
& $(6.63)$ & $(0.33)$ & $(1.49)$ \\
100 & $6.85^{\mathrm{c}}$ & $0.18^{\mathrm{c}}$ & $0.9^{\mathrm{c}}$ \\
& $(6.83)$ & $(0.18)$ & $(0.91)$ \\
Control & $5.2^{\mathrm{d}}$ & $0.38^{\mathrm{ab}}$ & $1.41^{\mathrm{b}}$ \\
& $(5.20)$ & $(0.36)$ & $(1.41)$ \\
CD $(p=0.05)$ & 1.113 & 0.077 & 0.437 \\
SEm \pm & 0.357 & 41.05 & 0.14 \\
\hline
\end{tabular}

*Figures in parentheses are square root transformed values

$100 \%$ inhibited the seedling growth (Table 5). This showed that the seedling growth was inversely proportional to effluent concentrations. The results are supported by findings of Dhanam (2009), who observed that lower concentrations of dairy effluent showed promoting effect on seed germination, seedling growth, and biomass production.

The results from Table 6 revealed that mustard seedlings

Table 6: Effect of dairy effluent on growth parameters of Mustard in petriplates

\begin{tabular}{lccc}
\hline $\begin{array}{l}\text { Concentration of } \\
\text { effluent }(\%)\end{array}$ & $\begin{array}{c}\text { Shoot length } \\
(\mathrm{cm})\end{array}$ & $\begin{array}{c}\text { Dry } \\
\text { weight }(\mathrm{g})\end{array}$ & $\begin{array}{c}\text { Wet weight } \\
(\mathrm{g})\end{array}$ \\
\hline 20 & $0.86^{\mathrm{de}}$ & $0.56^{\mathrm{a}}$ & $2.2^{\mathrm{a}}$ \\
& $(0.86)^{*}$ & $(0.56)$ & $(2.20)$ \\
40 & $0.9^{\mathrm{d}}$ & $0.24^{\mathrm{d}}$ & $0.9^{\mathrm{e}}$ \\
& $(0.91)$ & $(0.24)$ & $(0.90)$ \\
60 & $0.83^{\mathrm{e}}$ & $0.22^{\mathrm{d}}$ & $0.97^{\mathrm{d}}$ \\
& $(0.83)$ & $(0.22)$ & $(0.97)$ \\
80 & $1.42^{\mathrm{a}}$ & $0.43^{\mathrm{b}}$ & $1.41^{\mathrm{b}}$ \\
& $(1.42)$ & $(0.43)$ & 1.41 \\
100 & $1.29^{\mathrm{b}}$ & $0.33^{\mathrm{c}}$ & $1.28^{\mathrm{c}}$ \\
& $(1.29)$ & $(0.33)$ & $(1.28)$ \\
Control & $1.17^{\mathrm{c}}$ & $0.46^{\mathrm{b}}$ & $1.43^{\mathrm{b}}$ \\
& $(1.17)$ & $(0.46)$ & $(1.43)$ \\
CD $(p=0.05)$ & 0.072 & 0.058 & 0.07 \\
SEm \pm & 0.023 & 0.019 & 0.022 \\
\hline
\end{tabular}

*Figures in parentheses are square root transformed values showed maximum dry and wet weight i.e. $0.56 \mathrm{~g}$ and 2.20 $\mathrm{g}$ at $20 \%$ effluent in petriplates. In pot experiments also the maximum wet and dry weight of mustard seedlings were recorded at $20 \%$ effluent concentration (Table 7 ). However,

Table 7: Effect of dairy effluent on growth parameters of Mustard in pots

\begin{tabular}{lccc}
\hline $\begin{array}{l}\text { Concentration of } \\
\text { effluent }(\%)\end{array}$ & $\begin{array}{c}\text { Shoot length } \\
(\mathrm{cm})\end{array}$ & $\begin{array}{c}\text { Dry } \\
\text { weight }(\mathrm{g})\end{array}$ & $\begin{array}{c}\text { Wet weight } \\
(\mathrm{g})\end{array}$ \\
\hline 20 & $1.36^{\mathrm{c}}$ & $0.24^{\mathrm{b}}$ & $0.78^{\mathrm{c}}$ \\
& $(1.35)^{*}$ & $(0.24)^{*}$ & $(0.78)^{*}$ \\
40 & $2.01)^{\mathrm{a}}$ & $0.19^{\mathrm{c}}$ & $0.73^{\mathrm{c}}$ \\
& $(2.01$ & $(0.19)$ & $(0.73)$ \\
60 & $1.1^{\mathrm{d}}$ & $0.3^{\mathrm{a}}$ & $0.85^{\mathrm{b}}$ \\
& $(1.10)$ & $(0.30)$ & $(0.85)$ \\
80 & $1.95^{\mathrm{a}}$ & $0.26^{\mathrm{a}}$ & $1.04^{\mathrm{a}}$ \\
& $(1.95)$ & $(0.26)$ & $(1.04)$ \\
100 & $1.02^{\mathrm{e}}$ & $0.18^{\mathrm{c}}$ & $0.72^{\mathrm{c}}$ \\
& $(1.02)$ & $(0.18)$ & $(0.72)$ \\
Control & $1.56^{\mathrm{b}}$ & $0.27^{\mathrm{a}}$ & $0.76^{\mathrm{c}}$ \\
& $(1.55)$ & $(0.27)$ & $(0.76)$ \\
CD $(p=0.05)$ & 0.072 & 0.051 & 0.068 \\
SEm \pm & 0.023 & 0.016 & 0.022 \\
\hline
\end{tabular}

*Figures in parentheses are square root transformed values 
$100 \%$ dairy effluent retarded the growth of mustard seedling as shoot length measured as $1.02 \mathrm{~cm}$ and it also reduced the biomass production (0.18 g). Pandey and Soni (1994) also suggested that the interaction between the various constituents of the effluent and native microbes might be responsible for the inhibition of seedling growth.

\section{Conclusion}

The effluent sample at low concentration (20\%) showed a remarkable response in growth and germination compared to other concentrations. Since, the higher concentrations of the treated dairy effluent inhibits the plant growth, it is recommended that only after suitable dilution, dairy effluent can be effectively used for irrigation. However, some more extensive research work is needed to make such recommendation in order to minimize the risk.

\section{References}

Ahmad, T., Aadil, R.M., Ahmed, H., Rahman, U., Soares, B.C.V., Souza, S.L.Q., Pimentel, T.C., Scudino, H., Guimaraes, J.T., Esmerino, E.A., Freitas, M.Q., Almada, R.B., Vendramel, S.M.R., Silva, M.C., Cruz, A.G., 2019. Treatment and utilization of dairy industrial waste: A review. Trends in Food Science \& Technology 88, 361-372.

Al-Dulaimi, R., Ismail, N., Ibrahim, M., 2014. Responses on growth of ladyfinger (Abelmoschus esculentus L.) to different drug industry effluent. Electronic Journal of Environmental, Agricultural and Food Chemistry 5, 1598-1603.

American Public Health Association (APHA), 1998. Standard Methods for Examination of Water and Waste water. $20^{\text {th }} \mathrm{Ed}$.

Belyea, R.L., Williams, J.E., Gieseka, L., Clevenger, T.E., Brown, J.R., 1990. Evaluation of Dairy waste water solids as a feed ingredient. Journal of Dairy Science 73, 1864-1871.

Braio, V.B., Taveres, Granhem, C.R., 2007. Effluent generation by the dairy industry: preventive attitude and opportunities. Journal of chemical Engineering 24, 487-497.

Dhanam, S., 2009. Effect of dairy effluent on seed germination, seedling growth and biochemical parameter in paddy. Botany Research International 2, 61-63.

FAO, 1992. Wastewater treatment and use in agriculture. http://www.fao.org/3/t0551e/t0551e00.htm\#Contents

Gaikar, R.B., Uphade, B.K., Gadhave, A.G., Kuchekar, S.R., 2010. Effect of dairy effluent on seed germination \& early seedling growth of soyabeans. Rasayan Journal Chemistry 3, 137-139.

Khaleel, R.I.., Ismail, N., Ibrahim, M.H., 2012. The impact of waste water treatments on seed germination and biochemical parameter of Abelmoschus esculentus L. Procedia - Social and Behavioral Sciences 91, 453-460.

Kharbanda, A., Prasanna, K., 2016. Extraction of nutrients from dairy wastewater in the form of map (magnesium ammonium phosphate) and hap (hydroxyapatite).
Rasayan Journal of Chemistry 9, 215-221.

Koushik, P., Garg, V.K., Singh, B., 2005. Effect of textile effluents on growth performance of wheat cultivars. Bioresource Technology $96,1189-1193$.

Kumar, A., 2011. Effect of Dairy effluents on seed germination and early seedling growth of Pennisetum typhoides. International Journal of Research in Science \& Technology 1, 1-16.

Kumar, A., Das, A., Goel, M., Kumar, K.R., Subramanyam, B., Sudarsan, J.S., 2013. Recovery of nutrient from waste water through struvite crystallization. Nature, Environment and Pollution Technology 12, 479-482.

Lakshmi, S., Sundaramoorthy, P., 2003. Effect of chromium on germination and biochemical changes in blackgram. Journal of Ecobiology 15, 7-11.

Manu, K.J., Mohan Kumar, M.V., Mohana, V.S., 2012. Effect of dairy effluent (treated and untreated) on seed germination, seedling growth and biochemical parameters of maize (Zea mays L.). International Journal of Research in Chemistry and Environment 2, 62-69.

Mustafa, S., Ahmad, T., Naum, A., Shah, K.H., Wassum, M., 2010. Kinetics of chromium ion removal from tannery wastes using Amberliti IRA 400c and its hybrids. Water, Air and Soil pollution 210, 43-50.

Nagda, G.K., Diwan, A.M., Ghole, V.S., 2006. Seed germination bioassays to assess toxicity of molasses fermentation based bulk treatments methods of dairy waste water. Annals of Agricultural and Environmental Medicine 21, 42-48.

Pandey, D.K., Soni, P., 1994. Distillery effluent- a potential resource for irrigating forests seed beds. Ambio 23, 267-268.

Parmar, J.K., Bhanvadia, A.S., Ramani, V.P., Rathod, S., 2017. Effect of treated dairy effluent water on yield, nutrient content and uptake by castor-sorghum sequence. Nature, Environment and Pollution Technology 16, 279-286.

Prabhakar, P.S., Manisha, Mall, J., Singh, J., 2006. Impact of fertilizer factory effluent on seed germination, seedling growth and chlorophyll content of gram (Cicer aeritenum). Journal of Environmental Biology 27, 153-156.

Prasannakumar, P.G., Pandit, P.R., Kumar, R., 1997. Effect of dairy effluent on seed germination bioassays to assess toxicity of seed germination, seedling growth and pigment of green gram (Phaseolusareus L.) and black grameffluent. European Journal of Environment and (Phaseolus mungo L.). Advances in Plant Sciences 2, 146-149.

Ramjeawon, T., 2000. Cleaner Production in Mauritian Cane-sugar factories. Journal of Cleaner Production 8, 503-510.

Singh, A., Agrawal, S.B., Rai, J.P.N., Singh, P., 2002. Assessment of the pulp and paper mill effluent on growth, yield and 
nutrient quality of wheat (Triticum aestivum L.). Journal of Environmental Biology 23, 283-288.

Tikariha, A., Sahu, O., 2014. Study of characteristics and treatments of dairy industry waste water. Journal of Applied \& Environmental Microbiology 2, 16-22.

Verma, A., Singh, A., 2017. Physico-chemical analysis of dairy industrial effluent. International Journal of current microbiology and applied sciences 6, 1769-1775.

World Health Organization (WHO), 2003. Water Sanitation and Health (WSH). [Updated 2003; cited 31 July 2003]. Available from www.who.int/water_sanitation_health/ waste-water. 